\title{
20. Rb-Sr ISOTOPE SYSTEMATICS AND Sr/Ca-Ba/Ca RATIOS OF NAURU BASIN BASALTS, DEEP SEA DRILLING PROJECT LEG 891
}

\author{
Kenji Notsu, Institute of Chemistry, University of Tsukuba, Japan \\ Naoki Onuma, Department of Earth Sciences, Ibaraki University, Japan \\ and \\ Naoyuki Fujii, Department of Earth Sciences, Kobe University, Japan ${ }^{2}$
}

\begin{abstract}
Four samples of Nauru Basin basalts (Cores 94 to 109 of Hole $462 \mathrm{~A}$, sub-bottom depth $1077-1209 \mathrm{~m}$ ) have ${ }^{87} \mathrm{Sr} /{ }^{86} \mathrm{Sr}$ ratios in the range 0.7037 to 0.7038 , which is distinctly higher than the ratios of $\mathrm{N}$-type MORB. The Rb contents of the samples are depleted in comparison with those of MORB and ocean-island basalts. These chemical and isotopic characteristics are identical to those of the basalts previously drilled during Leg 61 (Cores 75 to 90 of Hole 462A), and are explained in terms of inhomogeneity of the source region in the mantle or later alteration effects.

$\mathrm{Sr} / \mathrm{Ca}-\mathrm{Ba} / \mathrm{Ca}$ systematics of 15 samples from Cores $462 \mathrm{~A}-94$ to $462 \mathrm{~A}-109$ and 14 samples from Cores $462 \mathrm{~A}-75$ to $462 \mathrm{~A}-90$ suggest that the Nauru Basin basalts are derived from a mantle peridotite by 20 to $30 \%$ partial melting with subsequent plagioclase crystallization.
\end{abstract}

\section{INTRODUCTION}

The Nauru Basin basalts cored in Hole 462A during DSDP Leg 61 have elemental abundances similar to those of N-type MORB, except that they have lower $\mathrm{K}$ and $\mathrm{Rb}$ concentrations and distinctly higher ${ }^{87} \mathrm{Sr} /{ }^{86} \mathrm{Sr}$ ratios than $\mathrm{N}$-type MORB (Fujii et al., 1981). Trace-element characteristics are intermediate between those of $\mathrm{N}$ - and $\mathrm{T}$ types of MORB (Batiza et al., 1980). Therefore, Tokuyama and Batiza (1981) proposed naming these peculiar basalts "ocean-plateau tholeiite," as a new type of basalt produced by intraplate volcanism.

One of the most interesting problems of the Nauru Basin basalts is their age. DSDP Site 462 lies on the magnetic anomaly between M26 and M27, which corresponds to about $155 \mathrm{Ma}$ (Larson and Schlanger, 1981), but the age of the basalts was determined to be Aptian $(\sim 110 \mathrm{Ma})$ from the fossils in the interbedded sediments (Site 462 report, this volume) and to be $110 \pm 3 \mathrm{Ma}$ by means of ${ }^{40} \mathrm{Ar}-{ }^{39} \mathrm{Ar}$ dating of one sample, 462A-32-1, 46-49 cm (Ozima et al., 1981). This age discrepancy casts doubt on the validity of the magnetic-anomaly age, unless the argument of Larson and Schlanger (1981) is accepted that anomalies M26 and M27 originate in the Pacific Plate basalts that presumably underlie the Aptian basalts.

On Leg 89 , the $1068.5 \mathrm{~m}$ of Hole $462 \mathrm{~A}$ cored during Leg 61 was deepened by $140.5 \mathrm{~m}$, to $1209 \mathrm{~m}$ sub-bottom (Leg 89 Scientific Party, 1983). The newly drilled section also contained basalt sheet-flows, which represent earlier stages of volcanism of the lower flows cored during Leg 61 . We characterize here the $\mathrm{Rb}-\mathrm{Sr}$ and $\mathrm{Sr} / \mathrm{Ca}-\mathrm{Ba} /$

\footnotetext{
${ }^{1}$ Moberly, R., Schlanger, S. O., et al., Init. Repts. DSDP, 89: Washington (U.S. Govt. Printing Office).

2 Addresses: (Notsu) Institute of Chemistry, University of Tsukuba, Sakura-mura, Ibaraki, 305 Japan; (Onuma) Dept. of Earth Sciences, Ibaraki University, Bunkyo, Mito 310, Japan; (Fujii) Dept. of Earth Sciences, Kobe University, Nada, Kobe 657, Japan.
}

Ca systematics of volcanic rocks in the Nauru Basin, using the newly drilled basalts, as a continuation of work on Leg 61 basalts (Fujii et al., 1981).

\section{EXPERIMENTAL METHODS}

Each sample was pulverized, using an agate mortar, to powder finer than 150 mesh. $\mathrm{Ba}, \mathrm{Sr}$, and Ca were determined by inductively coupled plasma-optical emission spectroscopy (Onuma et al., 1981).

For two samples, 462A-102-4, 3-5 cm and 462A-109-1, 106-108 cm, we removed the extremely fine grains ("fine whole rock") by settling in acetone. We then carried out a further density separation of the powder by centrifugation in mixed methylene iodide and acetone (densities of $2.62,2.90$, and $3.30 \mathrm{~g} / \mathrm{cm}^{3}$ ). Plagioclase is concentrated in the 2.62 to $2.90-\mathrm{g} / \mathrm{cm}^{3}$ fraction, and clinopyroxene is concentrated in the $>3.30-$ $\mathrm{g} / \mathrm{cm}^{3}$ fraction. $\mathrm{Rb}$ and $\mathrm{Sr}$ determinations were done using isotope dilution. For each sample, $\mathrm{Rb}-\mathrm{Sr}$ and ${ }^{87} \mathrm{Sr} /{ }^{86} \mathrm{Sr}$ analyses were done in 5 fractions: "whole rock," "fine whole rock," $2.62<\rho<2.90,2.90$ $<\rho<3.30$, and $\rho>3.30 \mathrm{~g} / \mathrm{cm}^{3}$. Details of strontium-isotope analyses were described by Notsu (1983). The measured range of ${ }^{87} \mathrm{Sr} /{ }^{86} \mathrm{Sr}$ ratios of NBS 987 standard was 0.71028 to 0.71033 , and the mean value was 0.71030 during the period of this study. Blanks for $\mathrm{Rb}$ and $\mathrm{Sr}$ throughout a whole procedure were approximately $0.3 \mathrm{ng}$ and $2.5 \mathrm{ng}$, respectively.

\section{RESULTS AND DISCUSSION}

\section{Bulk Rb-Sr Characteristics of the Nauru Basin Basalts}

Table 1 shows the results of $\mathrm{Rb}-\mathrm{Sr}$ and ${ }^{87} \mathrm{Sr} /{ }^{86} \mathrm{Sr}$ analyses. The ${ }^{87} \mathrm{Sr} / 86 \mathrm{Sr}$ ratios of the Leg 89 samples are 0.70372 to 0.70379 , identical to those of the lower sill basalts of the Nauru Basin (0.70358-0.70403; mean 0.70370) (Fujii et al., 1981). The Rb and Sr contents of the Leg 89 samples are also similar to those of the lower sill basalts. This is reasonable because the Leg 89 samples represent the continuation downward of the lower sills drilled during Leg 61 . We emphasize that the ${ }^{87} \mathrm{Sr} /$ ${ }^{86} \mathrm{Sr}$ ratios of the Nauru Basin basalts are distinctly higher than those of N-type MORB and similar to those of oceanic island basalts. We also confirm that the $\mathrm{Rb}$ contents are depleted relative to those in MORB and oceanic island basalts. This means either that the source re- 
Table 1. $\mathrm{Rb}$ and $\mathrm{Sr}$ contents and ${ }^{87} \mathrm{Sr} /{ }^{86} \mathrm{Sr}$ ratios of Hole $462 \mathrm{~A}$ basalts.

\begin{tabular}{lcccc}
\hline \multicolumn{1}{c}{ Sample } & $\mathrm{Rb}(\mathrm{ppm})^{\mathrm{a}}$ & $\mathrm{Sr}(\mathrm{ppm}){ }^{\mathrm{b}}$ & ${ }^{87} \mathrm{Rb} /{ }^{86} \mathrm{Sr}$ & ${ }^{87} \mathrm{Sr} /{ }^{86} \mathrm{Sr}^{\mathrm{c}}$ \\
\hline 94-6, 38-40 & & & & \\
& & & & \\
Whole rock & $0.85 \pm 7$ & 93 & $0.0246 \pm 20$ & 0.70372 \\
& & & & \\
102-4, 3-5 & & & & \\
& & & & \\
Whole rock & $0.40 \pm 2$ & 97 & $0.0120 \pm 6$ & 0.70375 \\
Fine whole rock & $0.81 \pm 2$ & 120 & $0.0196 \pm 5$ & 0.70372 \\
$2.62<\rho<2.90$ & $0.18 \pm 1$ & 185 & $0.0028 \pm 2$ & 0.70372 \\
$2.90<\rho<3.30$ & $0.25 \pm 2$ & 42 & $0.0174 \pm 14$ & 0.70370 \\
$\rho>3.30$ & $0.16 \pm 2$ & 6.3 & $0.075 \pm 9$ & 0.70390 \\
& & & & \\
$105-2,7-9$ & & & & \\
& & 99 & $0.0092 \pm 6$ & 0.70373 \\
Whole rock & $0.31 \pm 2$ & & & \\
& & & & \\
$109-1,106-108$ & & & & \\
Whole rock & $0.43 \pm 1$ & 102 & $0.0122 \pm 3$ & 0.70379 \\
Fine whole rock & $0.78 \pm 2$ & 124 & $0.0182 \pm 4$ & 0.70374 \\
$2.62<\rho<2.90$ & $0.22 \pm 2$ & 198 & $0.0032 \pm 3$ & 0.70366 \\
$2.90<\rho<3.30$ & $0.21 \pm 2$ & 92 & $0.0067 \pm 6$ & 0.70370 \\
$\rho>3.30$ & $0.16 \pm 2$ & 9.5 & $0.048 \pm 6$ & 0.70390 \\
\hline
\end{tabular}

Note: Density $(\rho)$ is in $\mathrm{g} / \mathrm{cm}^{3}$.

a Errors are $2 \sigma$ mean.

b $2 \sigma$ mean errors are less than $2 \%$.

c $2 \sigma$ mean error of each analysis is less than 0.00002 , but the reproducibility of the same sample is less than 0.00005 . So the uncertainty associated with each ratio is estimated to be \pm 0.00005 .

gion of the Naura Basin basalts has chemical and isotopic characteristics different from those of MORB or oceanic island basalts or that the later alteration effects have changed the original chemistry of the Nauru Basin basalts.

\section{The Attempt to Obtain Rb-Sr Internal Isochron Age}

The $\mathrm{Rb}-\mathrm{Sr}$ results of separated fractions of two samples show that for both samples $\mathrm{Rb}$ is concentrated in the "fine whole-rock" fraction and $\mathrm{Sr}$ is concentrated in the $2.62<\rho<2.90-\mathrm{g} / \mathrm{cm}^{3}$ fraction. According to the petrographic data for the thin section prepared from $462 \mathrm{~A}-102-4,7-8 \mathrm{~cm}$ (which is adjacent to our analyzed Sample 462A-102-4, 3-5 cm in the same rock piece) and for the thin section prepared from 462A-109-1, 100$103 \mathrm{~cm}$ (which is near Sample 462A-109-1, 106-108 cm), both samples have undergone alteration. Sample $462 \mathrm{~A}$ $109-1,100-103 \mathrm{~cm}$ is more abundant in clay minerals than Sample 462A-102-4, 7-8 cm (Site 462 report, this volume). Because clay minerals are more readily crushed finer, they are concentrated in the "fine whole-rock" fraction as a result of grain-size distinction in our separation procedure. Therefore, $\mathrm{Rb}$ may be enriched in this fraction. On the other hand, $\mathrm{Sr}$ is concentrated in plagioclase.

Figures 1 and 2 show the relationships between the ${ }^{87} \mathrm{Sr} /{ }^{86} \mathrm{Sr}$ and ${ }^{87} \mathrm{Rb} /{ }^{86} \mathrm{Sr}$ ratios for separated fractions of Samples 462A-102-4, 3-5 cm and 462A-109-1, 106-108 $\mathrm{cm}$, respectively. For both cases, the fractions with $\rho>$ $3.30 \mathrm{~g} / \mathrm{cm}^{3}$ have higher ${ }^{87} \mathrm{Rb} /{ }^{86} \mathrm{Sr}$ and ${ }^{87} \mathrm{Sr} /{ }^{86} \mathrm{Sr}$ ratios than the other four fractions, but it is difficult to determine precise ages at such low ${ }^{87} \mathrm{Rb} /{ }^{86} \mathrm{Sr}$ values $(<0.08)$ and in such young material. For the purpose of discus-

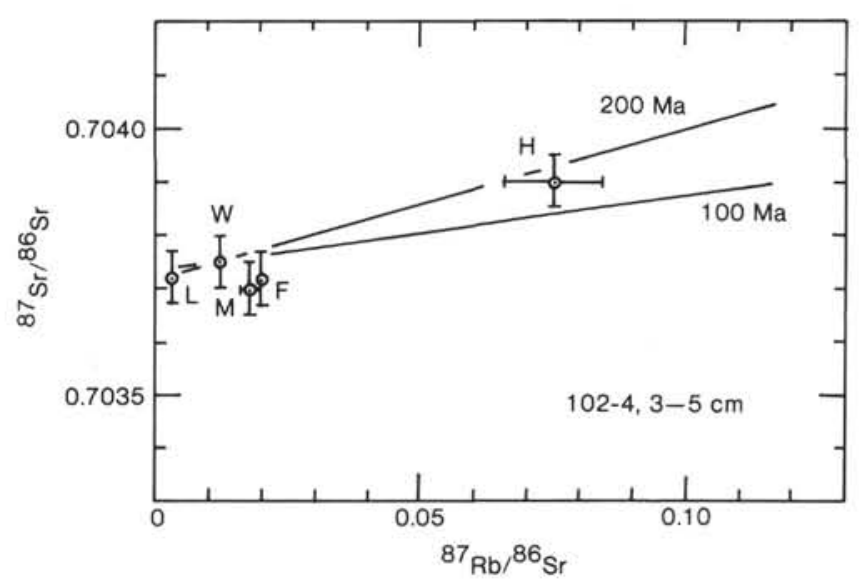

Figure 1. ${ }^{87} \mathrm{Sr} /{ }^{86} \mathrm{Sr}$ ratios versus ${ }^{87} \mathrm{Rb} /{ }^{86} \mathrm{Sr}$ ratios of Sample $462 \mathrm{~A}$ $102-4,3-5 \mathrm{~cm}$ basalt. W: whole rock. F: fine whole rock. L: 2.62 $<\rho<2.90 \mathrm{~g} / \mathrm{cm}^{3}$. M: $2.90<\rho<3.30 \mathrm{~g} / \mathrm{cm}^{3}$. H: $\rho>3.30 \mathrm{~g} /$ $\mathrm{cm}^{3} .100 \mathrm{Ma}$ and $200 \mathrm{Ma}$ reference lines are drawn to indicate a scale of age.

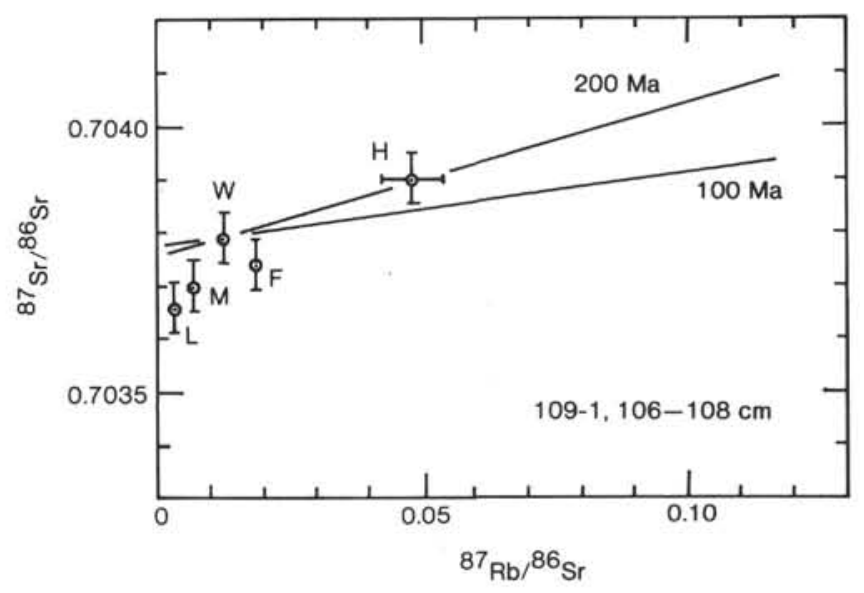

Figure $2 .{ }^{87} \mathrm{Sr} /{ }^{86} \mathrm{Sr}$ ratios versus ${ }^{87} \mathrm{Rb} /{ }^{86} \mathrm{Sr}$ ratios of Sample $462 \mathrm{~A}-109-1$, 106-108 cm basalt. W: whole rock. F: fine whole rock. L: $2.62<\rho$ $<2.90 \mathrm{~g} / \mathrm{cm}^{3}$. M: $2.90<\rho<3.30 \mathrm{~g} / \mathrm{cm}^{3}$. $\mathrm{H}: \rho>3.30 \mathrm{~g} / \mathrm{cm}^{3}$. $100 \mathrm{Ma}$ and $200 \mathrm{Ma}$ reference lines are drawn to indicate a scale of age.

sion, 100-Ma and 200-Ma reference lines are drawn through the "whole-rock" samples in both figures. If we assume that alteration occurred soon after cooling, we can only say that the $\mathrm{Rb}-\mathrm{Sr}$ data indicate that Samples 462A-102-4, 3-5 cm and 462A-109-1, 106-108 cm are more than several tens Ma but less than a few hundreds Ma. According to the Site 462 report (this volume), lower Aptian or older sediment was drilled at the sub-bottom depth of $1123 \mathrm{~m}$. Our estimate of $\mathrm{Rb}-\mathrm{Sr}$ age is consistent with the sediment age, but also includes the Jurassic age of the magnetic anomaly (Larson and Schlanger, 1981). A more precise absolute age of the Nauru Basin basalts is therefore a prerequisite for discussion of the nature of the primary magma generation.

A possibility remains, however, that, because of alteration, the Nauru Basin basalts may not give a meaningful $\mathrm{Rb}-\mathrm{Sr}$ age. During alteration, the original distri- 
bution of $\mathrm{Rb}$ and $\mathrm{Sr}$ in a rock is disturbed. By basaltseawater interaction at high temperature, $\mathrm{Rb}$ is leached from the rock and enriched in clay minerals (Menzies and Seyfried, 1979). As mentioned before, the two samples analyzed in this work contain clay minerals. It is not known whether such alteration disturbs the $\mathrm{Rb}-\mathrm{Sr}$ isochron in these samples.

\section{$\mathrm{Sr} / \mathrm{Ca}-\mathrm{Ba} / \mathrm{Ca}$ Diagram for Elucidation of Magma Genesis}

Figure 3 shows a $\mathrm{Sr} / \mathrm{Ca}-\mathrm{Ba} / \mathrm{Ca}$ diagram (SB diagram) (Onuma et al., 1983) for analysis of the partial melting process in the mantle and the fractional crystallization process in the magma chamber.

In mantle peridotite (for example, a garnet peridotite with chondritic $\mathrm{Sr} / \mathrm{Ca}$ and $\mathrm{Ba} / \mathrm{Ca}$ ratios), $\mathrm{Sr}^{2+}$ and $\mathrm{Ba}^{2+}$, with larger ionic radii, should be accommodated in accessory mineral phases such as apatite and phlogopite, whereas $\mathrm{Ca}^{2+}$, with smaller ionic radius, should be taken up in major mineral phases such as garnet and clinopyroxene, as well as in the accessory phases. Orthopyroxene and olivine do not accept $\mathrm{Ca}^{2+}, \mathrm{Sr}^{2+}$, or $\mathrm{Ba}^{2+}$.

A primary magma generated by small degrees of partial melting should have larger $\mathrm{Sr} / \mathrm{Ca}$ and $\mathrm{Ba} / \mathrm{Ca}$ ratios, since the accessory minerals are the first to melt. A primary magma with a larger degree of partial melting should have smaller $\mathrm{Sr} / \mathrm{Ca}$ and $\mathrm{Ba} / \mathrm{Ca}$ ratios because of addition of $\mathrm{Ca}^{2+}$ to the melt by decomposition of garnet and clinopyroxene. Melting and/or crystallization of olivine does not change $\mathrm{Sr} / \mathrm{Ca}$ and $\mathrm{Ba} / \mathrm{Ca}$ ratios of the melt.
If a series of primary magmas derived from a common mantle peridotite is available, we could expect to get a partial-melting line with a slope of about $45^{\circ}$ passing the mantle peridotite in the SB diagram. Primitive basalts from an island-arc region fall on a partial-melting line through a mantle peridotite with chondritic $\mathrm{Sr} /$ $\mathrm{Ca}$ and $\mathrm{Ba} / \mathrm{Ca}$ ratios. The slope of about $45^{\circ}$ means that the partial melting process is operating at nearly constant $\mathrm{Sr} / \mathrm{Ba}$ ratio with variable Ca supply. The degrees of partial melting marked on the line are calculated numbers based on a melting experiment of a garnet peridotite by Mysen and Kushiro (1977). A series of primary magmas derived from a Ba-enriched source ("fertile mantle") or from a Ba-depleted source ("depleted mantle") with the same $\mathrm{Sr}$ contents should make different partial melting lines, as shown in Figure 3.

Plagioclase and clinopyroxene fractionation of a primary magma can be studied using $\mathrm{Sr} / \mathrm{Ca}-\mathrm{Ba} / \mathrm{Ca}$ systematics. Olivine and magnetite crystallization cannot be visualized in the SB diagram, since these minerals do not accept $\mathrm{Ca}^{2+}, \mathrm{Sr}^{2+}$, or $\mathrm{Ba}^{2+}$. Orthopyroxene crystallization might increase $\mathrm{Sr} / \mathrm{Ca}$ and $\mathrm{Ba} / \mathrm{Ca}$ ratios of the primary magmas in negligibly small amount, because orthopyroxene accepts small amounts of $\mathrm{Ca}^{2+}$ but excludes $\mathrm{Sr}^{2+}$ and $\mathrm{Ba}^{2+}$. On the other hand, clinopyroxene, garnet, amphibole, and plagioclase crystallization changes $\mathrm{Sr} / \mathrm{Ca}$ and $\mathrm{Ba} / \mathrm{Ca}$ ratios of the primary magma drastically under the crystal-structure control of the $\mathrm{Ca}$, $\mathrm{Sr}$, and $\mathrm{Ba}$ partition between the magma and these minerals. As shown in Figure 3, a primary magma is evolved toward the upper right by clinopyroxene crystallization,

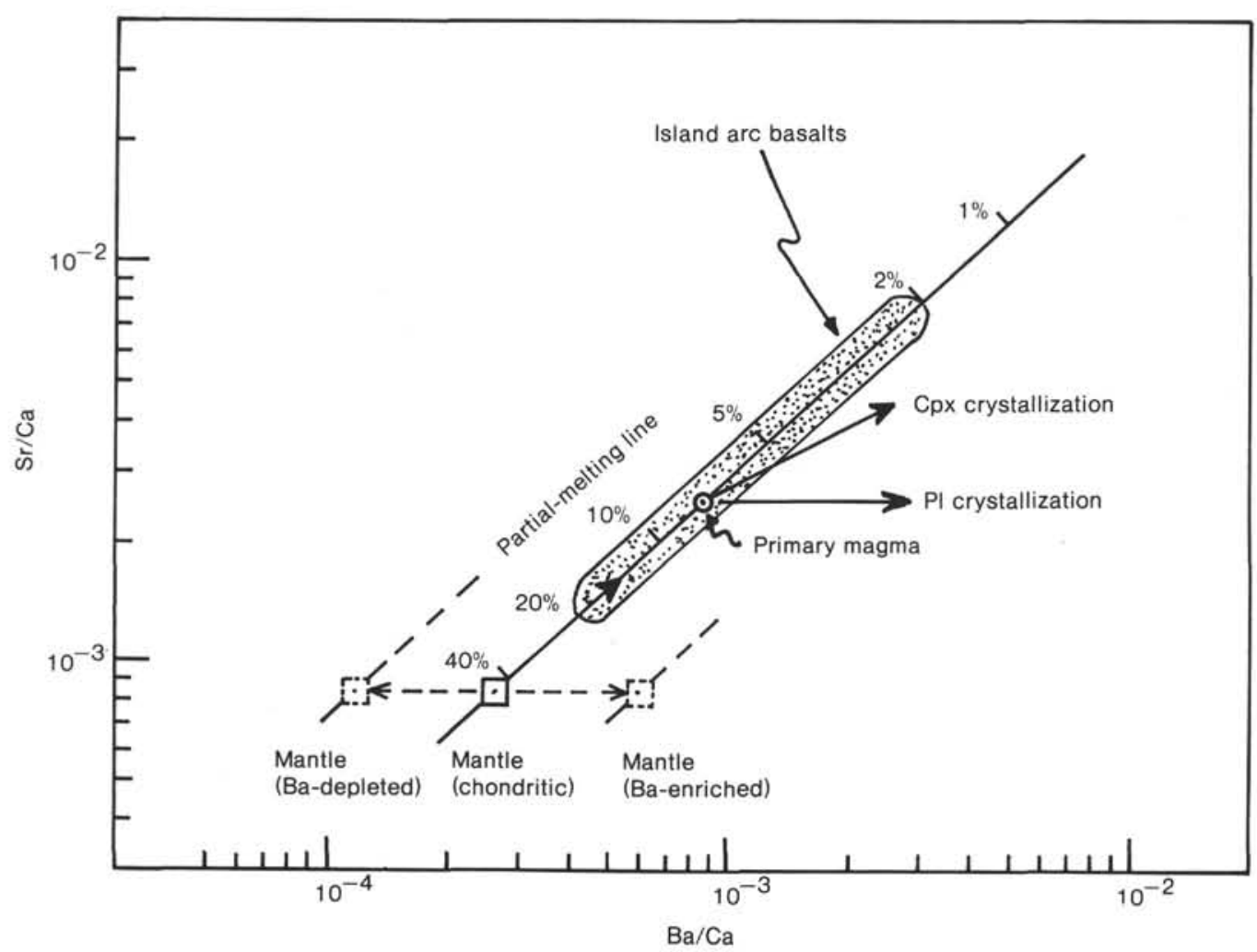

Figure 3. Schematic presentation of the principle of the $\mathrm{Sr} / \mathrm{Ca}-\mathrm{Ba} / \mathrm{Ca}$ diagram for elucidation of magma genesis. ( $\mathrm{Cpx}=$ clinopyroxene; $\mathrm{Pl}=$ plagioclase. $)$ 
whereas the magma is evolved toward the right by plagioclase crystallization.

\section{Nauru Basin Basalts on the $\mathrm{Sr} / \mathrm{Ca}-\mathrm{Ba} / \mathrm{Ca}$ Diagram}

Figure 4 shows an SB diagram for Nauru Basin basalts (Hole 462A, lower unit) along with the Reykjanes Ridge basalts (Hole 409). Data are taken from Table 2 and Fujii et al. (1981) for the Nauru Basin basalts and from Tarney et al. (1979) for the Reykjanes Ridge basalts.

As already pointed out by Fujii et al. (1981), Nauru Basin basalts are very similar to N-type MORB in their $\mathrm{Ca}, \mathrm{Sr}$, and $\mathrm{Ba}$ abundances. The Nauru Basin basalts and $\mathrm{N}$-type MORB are both depleted in Ba compared with the Reykjanes Ridge basalts. In other words, the Reykjanes Ridge basalts are more primitive than the socalled N-type MORB.

The Reykjanes Ridge basalts make a triangular region, whereas the Nauru Basin basalts make a horizontal band, on the SB diagram. The triangular region defined by the Reykjanes Ridge basalts suggests that (1) the source material is slightly depleted in Ba compared with a chondritic mantle, (2) most of the basalts are generated by 20 to $30 \%$ partial melting of the source material, with subsequent plagioclase crystallization, and (3) several basalts are derived from the source material by 7 to $15 \%$ partial melting without plagioclase crystallization. The horizontal band defined by the Nauru Basin basalts suggests, on the other hand, that (1) the source material is strongly Ba-depleted compared with the chon-
Table 2. $\mathrm{Ca}, \mathrm{Sr}$, and Ba contents (ppm) of Hole $462 \mathrm{~A}$ basalts.

\begin{tabular}{lrrrcc}
\hline $\begin{array}{c}\text { Sample } \\
\text { (interval in cm) }\end{array}$ & $\mathrm{Ca}$ & $\mathrm{Sr}$ & $\mathrm{Ba}$ & $\mathrm{Sr} / \mathrm{Ca}$ & $\mathrm{Ba} / \mathrm{Ca}$ \\
\hline $94-1,123$ & 77600 & 95 & 10 & $1.22 \times 10^{-3}$ & $1.3 \times 10^{-4}$ \\
$94-3,117$ & 79500 & 101 & 9 & $1.27 \times 10^{-3}$ & $1.1 \times 10^{-4}$ \\
$94-6,38-40$ & 77600 & 92 & 9 & $1.19 \times 10^{-3}$ & $1.2 \times 10^{-4}$ \\
$96-3,118-120$ & 77800 & 95 & 9 & $1.22 \times 10^{-3}$ & $1.2 \times 10^{-4}$ \\
$98-7,70-72$ & 80100 & 96 & 6 & $1.20 \times 10^{-3}$ & $0.7 \times 10^{-4}$ \\
$99-1,143-145$ & 78400 & 92 & 6 & $1.17 \times 10^{-3}$ & $0.8 \times 10^{-4}$ \\
$100-2,74$ & 77200 & 94 & 6 & $1.22 \times 10^{-3}$ & $0.8 \times 10^{-4}$ \\
$100-2,133-135$ & 77900 & 95 & 7 & $1.22 \times 10^{-3}$ & $0.9 \times 10^{-4}$ \\
$102-4,3-5$ & 77800 & 96 & 11 & $1.23 \times 10^{-3}$ & $1.4 \times 10^{-4}$ \\
$103-1,76-78$ & 79400 & 98 & 5 & $1.23 \times 10^{-3}$ & $0.6 \times 10^{-4}$ \\
$104-1,88-90$ & 78900 & 98 & 6 & $1.24 \times 10^{-3}$ & $0.8 \times 10^{-4}$ \\
$105-2,7-9$ & 78600 & 102 & 6 & $1.30 \times 10^{-3}$ & $0.8 \times 10^{-4}$ \\
$106-1,24$ & 78000 & 98 & 5 & $1.26 \times 10^{-3}$ & $0.6 \times 10^{-4}$ \\
$108-2,36-38$ & 76400 & 98 & 7 & $1.28 \times 10^{-3}$ & $0.9 \times 10^{-4}$ \\
$109-1,106-108$ & 79600 & 105 & 6 & $1.32 \times 10^{-3}$ & $0.8 \times 10^{-4}$ \\
\hline
\end{tabular}

dritic mantle, and (2) the basalts are derived from the source material by 20 to $30 \%$ partial melting with subsequent plagioclase crystallization, if we assume that $\mathrm{Sr}$ is fixed but $\mathrm{Ba}$ is mobile in the mantle.

Thus, the difference in $\mathrm{Ba}$ content between the Nauru Basin basalts and the Reykjanes Ridge basalts may be explained by different source materials. The source material for the Nauru Basin basalts corresponds to a "Badepleted" or "barren" mantle; the source material for the Reykjanes Ridge basalts corresponds to a "Ba-normal" or "normal" mantle.

There is an alternative explanation, however, for the difference between them. $\mathrm{Ca}$ and $\mathrm{Sr}$ are accommodated

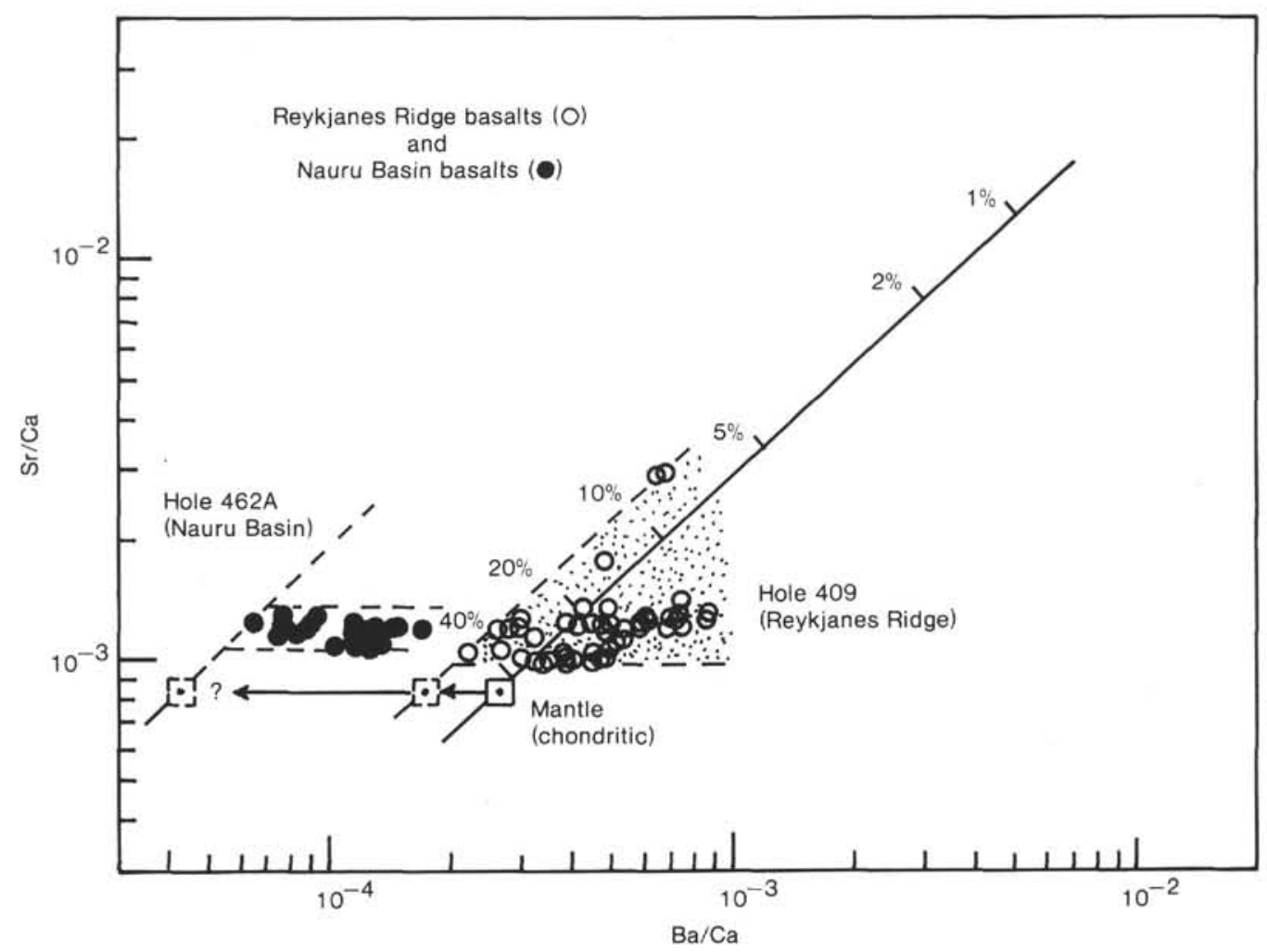

Figure 4. Comparison, based on $\mathrm{Sr} / \mathrm{Ca}-\mathrm{Ba} / \mathrm{Ca}$ systematics, of the Nauru Basin basalts and the Reykjanes Ridge basalts. 
in clinopyroxene and plagioclase in the basalts, but $\mathrm{Ba}$ is originally situated in the groundmass or glass, which is easily altered. Therefore, the possibility that $\mathrm{Ba}$ in the specimens had been leached out during the subsequent alteration process cannot be ruled out.

Whatever results follow, the SB diagram suggests that the Nauru Basin basalts are derived from a mantle peridotite by 20 to $30 \%$ partial melting with subsequent plagioclase crystallization.

\section{ACKNOWLEDGMENTS}

We are grateful to Dr. R. J. Stern and an anonymous reviewer for their critiques. We thank Mr. Y. Takaku and N. Nishida for their technical assistance in ICP-OES analysis. N.F. is particularly grateful to the co-chiefs and other scientists of Leg 89 for providing him a chance to join Leg 89 .

\section{REFERENCES}

Batiza, R., Larson, R. L., Schlanger, S. O., Shcheka, S. A., and Tokuyama, H., 1980. Trace element abundances in basalts of Nauru Basin. Nature, 286:476-478.

Fujii, N., Notsu, K., and Onuma, N., 1981. Chemical composition and $\mathrm{Sr}$ isotopes of Deep Sea Drilling Project Leg 61 basalts. In Larson, R. L., Schlanger, S. O., et al., Init. Repts. DSDP, 61: Washington (U.S. Govt. Printing Office), 697-700.

Larson, R. L., and Schlanger, S. O., 1981. Cretaceous volcanism and Jurassic magnetic anomalies in the Nauru Basin, western Pacific Ocean. Geology, 9:480-484.

Leg 89 Scientific Party, 1983. Leg 89 drills Cretaceous volcanics. Geotimes, 28(4):17-20.
Menzies, M., and Seyfried, W. E., Jr., 1979. Basalt-sea water interaction: Trace element and strontium isotopic variations in experimentally altered glassy basalt. Earth Planet. Sci. Lett., 44:463-472.

Mysen, B. O., and Kushiro, I., 1977. Compositional variations of coexisting phases with degree of melting of peridotite in the upper mantle. Am. Mineral., 62:843-865.

Notsu, K., 1983. Strontium isotope composition in volcanic rocks from the Northeast Japan arc. J. Volcanol. Geotherm. Res., 18:531-548.

Onuma, N., Hirano, M., and Isshiki, N., 1981. Sr/Ca-Ba/Ca systematics in four volcanoes of Oshima, Izu Islands, Japan. Geochem. J., 15:315-324.

1983. Genesis of basalt magmas and their derivations under the Izu Islands, Japan, inferred from $\mathrm{Sr} / \mathrm{Ca}$ and $\mathrm{Ba} / \mathrm{Ca}$ systematics. J. Volcanol. Geotherm. Res., 18:511-529.

Ozima, M., Saito, K., and Takigami, Y., $1981 .{ }^{40} \mathrm{Ar}-{ }^{39} \mathrm{Ar}$ chronological studies on rocks drilled at Holes 462 and 462A, Deep Sea Drilling Project Leg 61. In Larson, R. L., Schlanger, S. O., et al., Init. Repts. DSDP, 61: Washington (U.S. Govt. Printing Office), 701-703.

Tarney, J., Saunders, A. D., Weaver, S. D., Donnellan, N. C. B., and Hendry, G. L., 1979. Minor-element geochemistry of basalts from Leg 49, North Atlantic Ocean. In Luyendyk, B. P., Cann, J. R., et al., Init. Repts. DSDP, 49: Washington (U.S. Govt. Printing Office), 657-691.

Tokuyama, H., and Batiza, R., 1981. Chemical composition of igneous rocks and origin of the sill and pillow-basalt complex of Nauru Basin, South Pacific. In Larson, R. L., Schlanger, S. O., et al., Init. Repts. DSDP, 61: Washington (U.S. Govt. Printing Office), 673-687.

Date of Initial Receipt: 22 May 1984 Date of Acceptance: 22 August 1984 